\title{
MORPHOPHYSIOLOGICAL EVALUATION OF Bauhinia divaricata L. (Fabaceae) PLANTS AT DIFFERENT WATER REGIMES
}

\author{
AVALIAÇÃO MORFOFISIOLÓGICA EM PLANTAS DE Bauhinia divaricata $L$. \\ (Fabaceae) EM DIFERENTES REGIMES HÍDRICOS
}

\author{
Magnólia Martins ALVES ${ }^{1}$; Manoel Bandeira de ALBUQUERQUE²; \\ Walter Esfrain PEREIRA ${ }^{2}$; Victor Junior Lima FELIX ${ }^{3}$; João Pedro da Silva AZEVEDO ${ }^{4}$ \\ 1. Programa de Pós - Graduação em Agronomia, Universidade Federal da Paraíba, Areia, PB, Brasil. magecologia@ hotmail.com; 2. \\ Professor, Doutor, Universidade Federal da Paraíba, Centro de Ciências Agrárias, Areia, PB; 3. Programa de Pós - Graduação em \\ Ciência do Solo, Universidade Federal da Paraíba, Areia, PB, Brasil; 4. Engenheiro Agrônomo, Universidade Federal da Paraíba, Areia,
} PB, Brasil.

\begin{abstract}
The pata-de-vaca (Bauhinia divaricata L.) tree is a species widely distributed in Brazil, it has a high ornamental and economic value. Its leaves are used in renal inflammations, such as diuretic, hypoglycemic, being considered a medicinal plant of popular use. The research was carried out in a greenhouse belonging to the Laboratório de Ecologia Vegetal, at the Centro de Ciências Agrárias (CCA), from Universidade Federal of Paraíba (UFPB). The objective was to evaluate the morphophysiological characteristics of $B$. divaricata plants at different water regimes. The experimental design was completely randomized with five water treatments 1 (100\% control), 2 (80\%), $3(60 \%), 4$ (40\%) and $5(20 \%)$ of the container capacity. The height, number of leaves and stem diameter were evaluated weekly. At the end of the experiment the plants had their organs separated and taken to the greenhouse to obtain the dry matter of the leaves, stem, roots and total dry matter, and also, biomass allocation in the leaves, stem and roots. Plant height did not differ statistically between the treatments. The number of leaves, diameter, leaf, stem and root allocation and root and shoot dry matter were higher under water availability (100\% of container capacity). For the production of B. divaricata L. seedlings water regime should be $100 \%$ and $80 \%$ of the container capacity, but the seedlings grow satisfactorily.
\end{abstract}

KEYWORDS: Florestal species. Dry matter. Seedlings production.

\section{INTRODUCTION}

The dry season is a period where the water deficit in plants can be observed in a more common way, because the water present in the soil is not available for small or long periods, causing a reduction of the physiological activities of the plant species (CAVALCANTE et al. 2009).

In addition, it may lead to reduction in cell expansion, reduction in leaf area, increase in leaf abscission, decrease in the relationship between root biomass and shoot, stomata closure and consequently the reduction of photosynthesis (DUTRA et al., 2012).

According to Silva et al. (2009) with the reduction in the photosynthetic rate associated with stomatal closure due to changes in the water status of the leaf, there is possibility of death by desiccation.

Many native tree species are potentially suitable for cultivation, and may serve various purposes whether for ornamental value, timber, food or preservation of degraded areas.

Thus, the improvement of the seedling production system of native tree species is necessary, due to the increase in demand for such species for commercial production, as well as revegetation of degraded areas and riparian forests, reforestation, commercial fields, makes the production of quality seedlings a fundamental practice for the success of these activities (BRIENZA JR., 2008; FERRAZ AND ENGEL, 2011; SANTOS et al., 2012).

Leguminosae (Fabaceae) make up an important group of plants and represent most of the floristic diversity of the Northeast region of Brazil and the Caatinga Domain, where 603 species have already been registered (BFG 2015). In Brazil, it is the best represented family with 2.807 species grouped in 222 genera (15 endemic) abundant in almost all the biomes and ecosystems of the country (BFG 2015)

Bauhinia divaricata L. belongs to the Fabaceae family, commonly known as a pata-devaca, unha de boi, and it is a species distributed throughout Brazil, occurring at the edges of the forests, and can be found in the form of a shrub, a tree that can reach up to six meters high. Its leaves are used in the alternative medicine for renal inflammation, being considered a medicinal plant of popular use (LORENZI, 2012).

With accelerated deforestation and loss of biodiversity, there is a need to increase knowledge about Brazilian flora, especially in arid regions, 
where plants suffer from water stress. The objective of this study was to evaluate the morphophysiological characteristics of $B$. divaricata L. plants at different water regimes.

\section{MATERIAL AND METHODS}

The research was carried out in a greenhouse belonging to the Laboratório de Ecologia Vegetal, at the Department of plant and environmental sciences, of the center of agricultural sciences (CCA), from the Universidade Federal of Paraíba (UFPB).

The climatic conditions of the greenhouse relative to the temperature were monitored during a period of 84 days that was carried out the experiment. The average minimum temperature was not less than $25{ }^{\circ} \mathrm{C}$ in the morning hours, and the maximum did not exceed $31^{\circ} \mathrm{C}$.

The fruits of $B$. divaricata were collected directly from mother trees located in the city of Areia, PB. They were taken to the Laboratory of Plant Ecology, where they were manually benefited to obtain the seeds, they were submitted to the emergence in the region opposite to the hilo to overcome the dormancy, following the methodology of Alves et al. (2004).

The seeds were placed to germinate on germitest paper, where it was moistened with distilled water in the amount equivalent to 2.5 times the dry paper mass. Placed in germinating chamber of type Biochemical Oxigen Demand (B.O.D.) adjusted to the temperature $30{ }^{\circ} \mathrm{C}$ constant.

Subsequently, normal seedlings with perfect structure were selected and placed in pots with capacity of 5 liters with soil collected in the area of origin of the seeds. The soil had the following chemical composition: $\mathrm{pH}: 5,20$; P: 116.15; K: 55.89; $\mathrm{Na}: 0.24 ; \mathrm{Ca}+\mathrm{Mg}$ : 10.81; Ca: 9.44; $\mathrm{Mg}$ : 1.37; Al: 0.00; H + Al: 2.31; C: 2.84; M.O: 4.90; SB: 11.19; CTC: 13.50; V\%: 82.89.

During 30 days in the acclimatization phase after sowing, the plants were maintained in field capacity, with irrigation daily or when it was necessary.

After this period, the treatments were applied by means of daily weighing of each pot, where water was added until reaching the corresponding weight of each treatment.

The experimental design was completely randomized with five treatments, corresponding to 1 (100\% control), 2 (80\%), 3 (60\%), $4(40 \%)$ and 5 $(20 \%)$ of the container capacity, with eight replications for each treatment, totaling 48 seedlings. The pot capacity was accessed through gravimetric method described by Souza et al. (2000).

The growth evaluation was performed weekly, measuring plant height (AP) using a millimetric ruler measured from the stem base until insertion of the last leaf, stem diameter (DC) with a digital caliper with an accuracy of $0.002 \mathrm{~mm}$, and number of leaves (NF) completely expanded, counting the number of leaves, was performed counting the number of leaves in each plant of each treatment.

At the end of the experiment at 85 days, the plants were separated into leaves, stems and roots. For the length of roots, they were measured with an aid of millimeter rule.

Afterwards the leaves, stems and roots were packed in Kraft paper bags for drying in forced circulation air oven with a temperature of $65^{\circ} \mathrm{C}$ until constant weight was obtained. From the data of dry matter, it was calculated the biomass allocation to the leaves (BAL), stems (BAS), and roots (BAR) according to Benincasa (1988).

At 65 days after sowing, the gas exchange was evaluated using an IRGA LC-Pro Sd Portable, ADC BioScientific, UK. Measurements were always made on the leaves of the middle third of each plant in the period from 10 to $12 \mathrm{~h}$ at the morning. As a light source, a lamp which provided a photosynthetically active radiation (RFA) intensity of $1,200 \mu \mathrm{mol} \mathrm{m} \mathrm{m}^{-2}$. The rates of leaf temperature $\left({ }^{\circ} \mathrm{C}\right)$, internal carbon $(\mathrm{Ci})$, transpiration $(E)$, stomatal conductance $(G s)$, liquid photosynthesis $(A)$, and the efficiency in water use.

The data were submitted to analysis of variance, the means compared to each other by the Tukey test at 5\% probability. The height and leaf number data were submitted to a polynomial regression analysis using $S A S$ software.

\section{RESULTS AND DISCUSSION}

Statistical analysis showed that there were no significant differences between treatments for the height of $B$. divaricata plants during the experimental period (Figure 1A). It can be stated in the present research that in this situation the plants responded in a similar way to the action of the different water regimes.

Regarding the number of leaves, the plants of $B$. divaricata when submitted to the $100 \%$ CC treatment presented the highest averages in the emission of new leaves (4.93 leaves), for the treatments 80, 60 and $40 \%$ of $\mathrm{CC}$ were not Observed a significant difference between the water regimes, in the $20 \% \mathrm{CC}$ treatment, water stress 
reduced the emission of new leaves by $50 \%$ compared to the treatment 100\% [(control (Figure 1B)]. These results demonstrate that the species, although surviving the Stress, has no ability to produce new tissues.
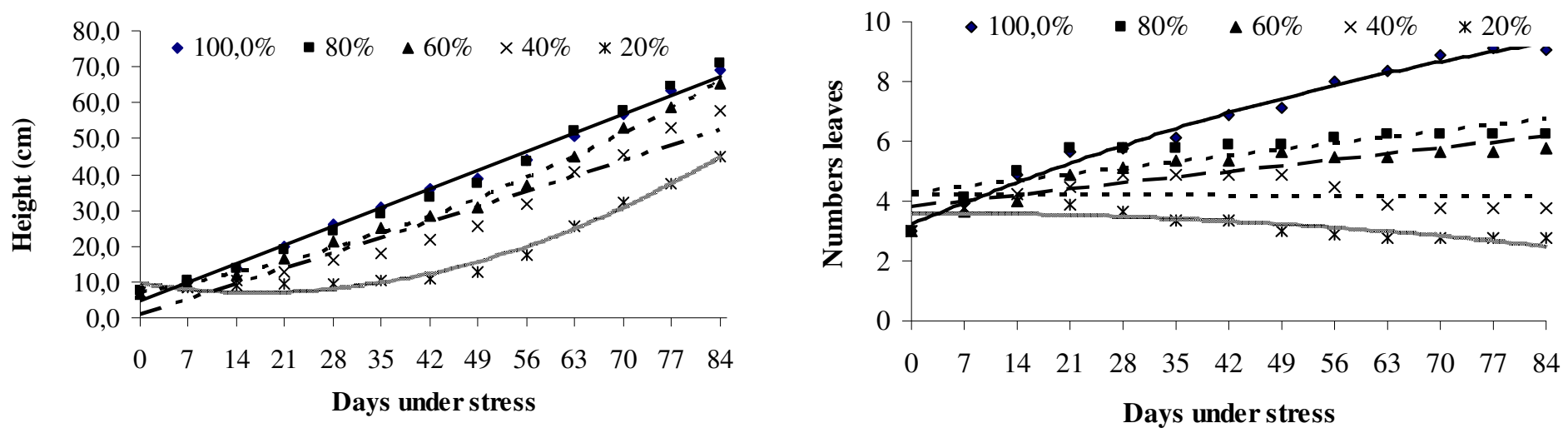

Figure 1. Plant height (A) and num ${ }^{-}$A es (B) of Bauhinia divaricata L. on different water $\mathrm{rt}_{\text {B }}$

Probably this reduction in the number of leaves may be related to the decrease in the transpiratory rate, so there was less water loss.

From the results obtained, we can indicate that $B$. divaricata is a species sensitive to water stress and this sensitivity was more accentuated in the number of leaves, mean a defense mechanism of the plant under stress conditions, limiting the loss of water by transpiration. However, under conditions of water stress, the plants reduce the emission of new leaves and the leaf area, and this may lead to a decrease in the photosynthetic capacity of the vegetable (SILVA et al., 2011).

According to Santos et al. (2014), plant growth depends on the division and expansion of its cells, the latter being conditioned to the pressure of turgidity, a process affected by the low availability of water in the soil.

However, results obtained by Padilha et al. (2016) (Jatropha curcas L.), the treatments of 60 and $100 \%$ of the water retention capacity in the soil resulted in higher plant height. It can be affirmed that the resurgence of new leaves, which apparently became slower in $B$. divaricata plants under severe water stress, probably because it is a defense mechanism that the plant uses, as well as reduction of leaf area.

For the variables stem diameter and root length, they promoted significant effects in all studied periods (Figure 2).

The influence of water availability, the control-treatment plants $(100 \%$ CC) were the highest values, followed by the plants of the treatments $80,60,40 \%$ of $\mathrm{CC}$, and those of the treatments with $20 \% \mathrm{CC}$, showing reductions of
$54.51 \%$ in comparison to the control treatment. Thus, it can be inferred that the reduction in water availability limited the growth in stem diameter of B. divaricata. This reduction in stem diameter can be related to the reduction of available water in the soil, leading to the plant requiring more energy to absorb water and develop (LEONARDO et al., 2007).

Evaluating the biometric parameter of the root length, a statistical difference was observed only between the $20 \%$ CC treatments, with a reduction of $51.8 \%$ compared to the control treatment (Figure 2B).

When a plant species is submitted to water stress has practically all aspects of the growth and development affected, which may imply modifications in their morphology and even interfere with many metabolic reactions (ACHAKZAI, 2009).

According to Albuquerque et al. (2013), evaluating the influence of available soil water levels in the growth in the caulinar diameter of the pinhão-manso (Jatropha curcas) observed, at 150 days after sowing, the largest stem diameter occurred in the treatment with $100 \%$ of $\mathrm{AD}$ in the soil. Results found by Martins et al. (2010), verified that the behavior of the stem diameter of nimindiano (Azadirachta indica A. Juss) in the controltreatment plants (100 and $80 \%$ of $\mathrm{CC}$ ) were those with the largest stem diameter.

Results found by Nascimento et al. (2011) in jatobá (Hymenaea courbaril L.) there was a reduction of $31.0 \%$ in relation to the plants grown with $100 \%$ CC. 

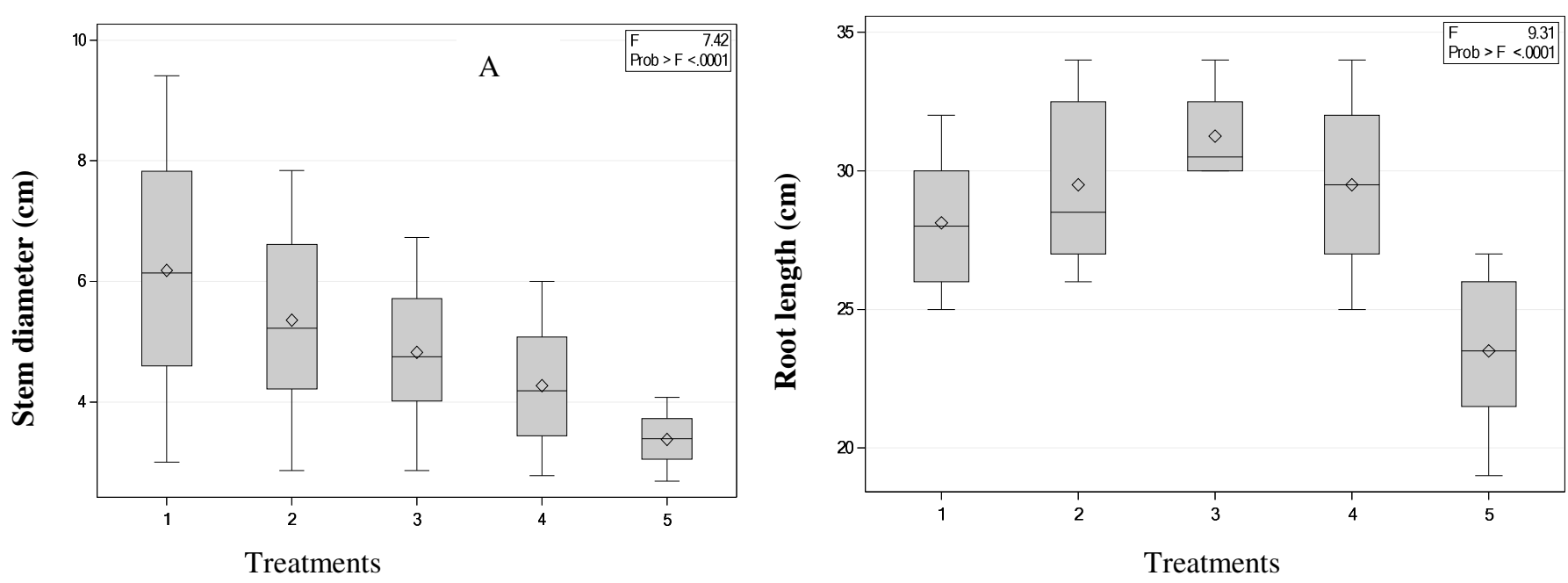

Figure 2. Stem diameter and root length of Bauhinia divaricata L. on different water regimes, $1(100 \%$ control), 2 (80\%), $3(60 \%), 4(40 \%)$ and $5(20 \%)$ of the CC.

However, when the water deficit develops in the field, in a slower way, it can impair the vegetative growth since under potting conditions there is limitation to the root growth (CHAVARRIA et al., 2015).

Results found by Dresch et al. (2016) evaluating the initial growth of Campomanesia adamantium (Cambess.) seedlings verified that root growth was more evident when seedlings were cultivated in red latosol + Bioplant, red latosol + sand and red latosol, with a water retention capacity of $80 \%, 64 \%(19.68 \mathrm{~cm}), 97.09 \%(19.77 \mathrm{~cm})$, and $100 \%(16.18 \mathrm{~cm})$ respectively.

The water deficit submitted to $B$. divaricata plants was sufficient to reduce the development of dry matter of leaves (DML) dry matter of stems (DMS) and dry matter roots (DMR) (Figure 3).

Plants submitted to $100 \%$ and $80 \% \mathrm{CC}$ treatments resulted in higher MSF content, with a mean of 1.536 and $1.395 \mathrm{~g}$, respectively. The treatments $60 \%$ and $40 \%$ did not differ statistically, had values of 1.300 and 1.256 respectively. The lowest accumulation of dry mass was obtained with the $20 \%$ CC regime, reducing its SPS by $49.8 \%$ in relation to the $100 \% \mathrm{CC}$ treatment. According to Dan Tatagiba et al. (2015), this difference shows that the leaves are more sensitive organs than the stem under water stress condition, due to both leaf fall and leaf blade reduction.

In relation to the DMS, the plants under $100 \%$ CP treatment had a superior result but did not statistically differ from the $80 \% \mathrm{CC}$ treatment, from the $60 \%$ CC treatment the applied water stress significantly reduced the dry stem mass, with a reduction of $17.32 \%$ when compared to the $100 \%$ $\mathrm{CP}$ treatment.

The DMR had higher content with the highest availability of water in the control treatment $100 \% \mathrm{CC}(4.344 \mathrm{~g})$ in the treatments $80 \%$ and $60 \%$ did not differ statistically, being lower in treatments $40 \%$ and $20 \% \mathrm{CC}$ with a reduction of $17.95 \%$ in relation to the controlling treatment of $100 \% \mathrm{CC}$.

For Lenhard et al. (2010) the dry matter of the root was higher when the seedlings were cultivated with $70 \%$ and $40 \%$ CC. The water deficit, when causing the superficial drying of the soil, stimulates the root expansion, which deepens in the soil in search of moisture (GONÇALVES, 2013; SCALON et al., 2011).

Such defense mechanisms may be detrimental to the full growth and development of the plant, but it can guarantee survival, provided that the water deficit is not highly severe and prolonged (GONÇALVES, 2013).

The dry mass of Jatropha curcas did not show any effect of the variable water regime analyzed, since less accumulation of dry matter was obtained with the $20 \% \mathrm{CC}$ regime (PADILHA et al., 2016).

Analyzing jointly, water stress negatively affected DMS and DMR, such behavior may be related to the mechanism of water stress tolerance, because prioritization of root growth occurs, providing greater capacity to absorb water and nutrients. 


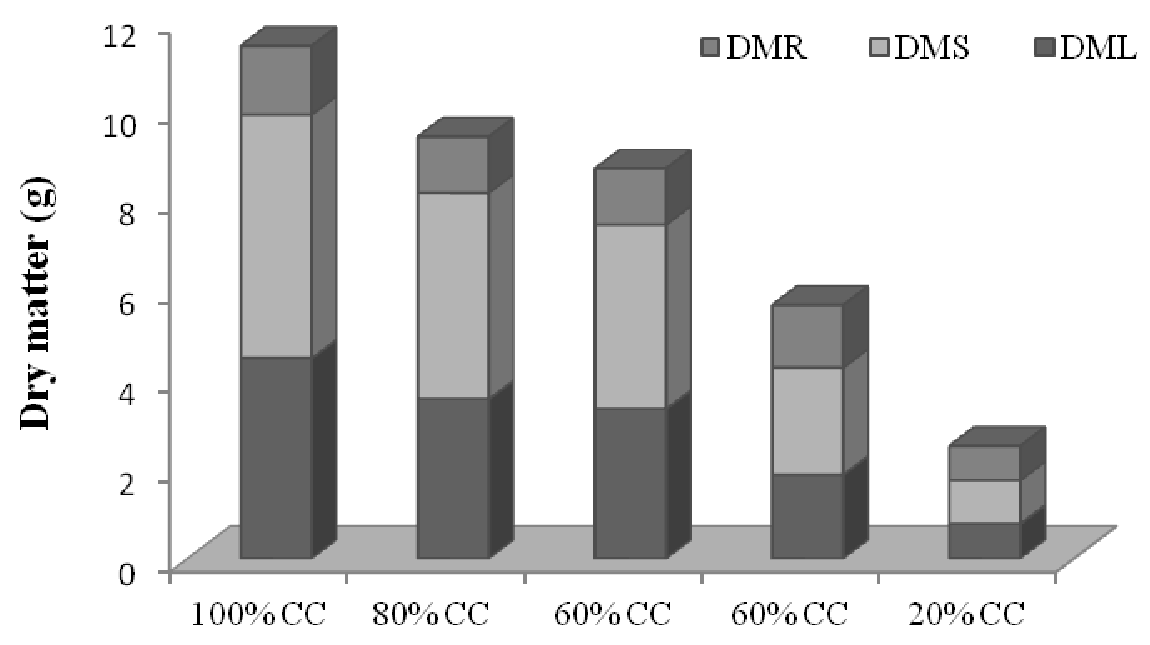

Figure 3. Dry matter of leaves, dry matter of stems and dry matter of roots of Bauhinia divaricata L. on different water regimes.

The analysis of the biomass allocation in the different compartments showed that there were no significant differences between the evaluated variables, proving that the water stress did not affect the biomass allocation of leaves, stems and roots (Table 1).

Table 1. Average values of biomass allocation of leaves, stems and roots of Bauhinia divaricata L. on different water regimes.

\begin{tabular}{cccc}
\hline Water availability & \multicolumn{3}{c}{ Biomass allocation (\%) } \\
\cline { 2 - 4 } & Leaves & Stems & Roots \\
\hline $1(100 \%$ CC $)$ & $0.134 \mathrm{a}$ & $0.127 \mathrm{a}$ & $0.126 \mathrm{a}$ \\
$2(80 \% \mathrm{CC})$ & $0.139 \mathrm{a}$ & $0.126 \mathrm{a}$ & $0.124 \mathrm{a}$ \\
$3(60 \% \mathrm{CC})$ & $0.110 \mathrm{a}$ & $0.126 \mathrm{a}$ & $0.120 \mathrm{a}$ \\
$4(40 \% \mathrm{CC})$ & $0.107 \mathrm{a}$ & $0.124 \mathrm{a}$ & $0.111 \mathrm{a}$ \\
$5(20 \% \mathrm{CC})$ & $0.104 \mathrm{a}$ & $0.122 \mathrm{a}$ & \\
\hline
\end{tabular}

Means followed by the same letter in the column are statistically equal to each other by the Tukey test at 5\% significance.

However, for the Nim-Indian species (Azadirachta indica A. Juss) the control treatments, with $80 \%$ and $60 \%$ of CC, leaf biomass allocation was the highest (MARTINS et al., 2010). Similar results were found by Nascimento et al. (2011) studying the jatobá (Hymenaea courbaril L.) species, the water stress did not affect the phytomass allocation among the evaluated variables, biomass allocation of leaves, stem and roots. Alves et al. (2017) studying morpho-physiological analyzes in plants of Allamanda blanchetii under under water deficit showed biomass allocation only to the leaves.

Evaluating the total biomass, it was verified that the highest values were found in the plants of the treatments 100 and $80 \%$ of $\mathrm{CC}$, with the respective averages of 11.162 and $9.722 \mathrm{~g}$. The plants of the treatments with 60 and $40 \%$ of CC were with values of 8.889 and $5.672 \mathrm{~g}$ respectively.
For the root / shoot ratio of B. divaricata the water regime was higher in plants grown with $100 \%$ $\mathrm{CC}$ and $80 \% \mathrm{CC}$ with averages of 0.954 and 0.945 respectively, the behavior of the plants decreased $(56.28 \%)$ with the increase of hydrical stress. Thus, it may be a strategy of the species under study, which may be related to the equilibrium in the growth between root and shoot, that there was a need to invest specifically in its root deepening (Figure 5).

The lowest averages were of $2.460 \mathrm{~g}$ in the plants of the treatments with $20 \%$ of CC. This result indicates that the appropriate strategy, since the excessive biomass requires a higher amount of water in the soil due to the greater total transpiration of the plant (BERNIER et al., 2008).

The results of the present research corroborate with Martins et al., (2010) that obtained the highest values of total dry matter in the treatments with higher water levels $(100 \%$ and $80 \%$ 
of CC) in young nim-indiano (Azadirachta indica A Juss).

Achten et al. (2010) researching Jatropha curcas found that the application of stress (40\% of the field capacity), reduced the total biomass production. According to (LENHARD et al., 2010), this higher ratio between root and shoot is due to the fact that it has a greater tuberosity in the main root, lower plant height and lower shoot weight.

However, Scalon et al. (2011) reported that the root architecture and its exploitation capacity in the deeper and humid layers of the soil, together with a greater ratio between root and shoot, are important characteristics of escaping water deficits.

Reduced values of all compartments of the species under study, such as stem diameter, number of leaves, total dry matter, under water stress indicate that the growth of this species is highly sensitive to water stress. The deepening of the root system allows the capture of water and salts in deeper layers of the soil, where there is greater availability of water.

Table 2. Total biomass and root / shoot ratio of Bauhinia divaricata L. on different water regimes.

\begin{tabular}{lcc}
\hline Water availability & Total biomass & Relation root / aerial part \\
\hline $1(100 \%$ CC $)$ & $11.161 \mathrm{a}$ & $0.953 \mathrm{a}$ \\
$2(80 \%$ CC) & $9.721 \mathrm{ab}$ & $0.944 \mathrm{a}$ \\
$3(60 \%$ CC $)$ & $8.888 \mathrm{~b}$ & $0.869 \mathrm{~b}$ \\
$4(40 \%$ CC $)$ & $5.672 \mathrm{c}$ & $0.748 \mathrm{c}$ \\
$5(20 \%$ CC $)$ & $2.460 \mathrm{~d}$ & $0.536 \mathrm{~d}$ \\
\hline
\end{tabular}

Means followed by the same letter in the column are statistically equal to each other by the Tukey test at 5\% significance.

The results of the analysis of variance regarding the physiological characteristics of $B$. divaricata plants carried out at 65 days after sowing are shown in table 5.

The behavior of the plants of $B$. divaricata on the photosynthetic rates of leaf temperature (Tf) and the internal carbon $(C i)$, showed a quadratic regression effect, as well as other gas exchange rates (transpiration, photosynthesis and water use efficiency USA) presented significant linear regressions for the effect of the water regime.

By analyzing the foliar temperature $(T f)$ on the gas exchanges, it was observed the increase in the $60 \% \mathrm{CP}$ treatment, when the effect of temperature elevation and water restriction is associated, it is visible a reduction of $\mathrm{CO}_{2}$ assimilation rates of $B$. divaricata plants with the reduction of photosynthesis and a fall in stomatal conductance, which probably resulted in an increase in internal $\mathrm{CO}_{2}$ concentrations in the mesophyll.

In relation to the transpiration increased linearly with the increase of the water supply to the plants, for this same condition was also verified linear increase in the proportion that increased the availability of water in the photosynthesis rates (Figure 5C and E), respectively. Probably there may have been limitations in the diffusion of $\mathrm{CO}_{2}$ into the mesophyll due to the occurrence of stomatal closure, which also limited water losses through transpiration (SIMÕES et al. 2015).

The reduction of transpiration occurs due to the stomatal closure, which is one of the first responses of the plant to the reduction of water availability.

According to Taiz and Zeiger (2017), the reduction of photosynthesis occurs in response to more severe water deficit conditions, in a stage after the reduction of shoot growth and the stimulation of root growth in depth, when water availability is not more sufficient to supply the plant metabolism. According to Sapeta et al. (2013) found strong evidence that stomatal conductance of Jatropha curcas may be related to soil moisture content rather than leaf turgor.

Therefore, reduction of stomatal conductance under water stress conditions may not be related to the reduction of leaf moisture content (POMPELLI et al., 2010; ARCOVERDE et al., 2011), but may be related to other factors such as plant abscisic acid hormonal, which according to Wilknson; Davies, (2002) originates in roots functions to minimize water loss due to transpiration.

The reduction of transpiration occurs due to the stomatal closure, which is one of the first responses of the plant to the reduction of water availability. According to Larcher (2006), under normal conditions, the transpiration rate in leaves is determined especially by radiation, saturation deficit and stomatal conductance. According to Mariano et al. (2009) when evaluating the photosynthesis in aroeira (Myracrodruon urundeuva) under irrigation suspension, it was observed that after 5 days without water the photosynthesis was reduced by $42 \%$. 

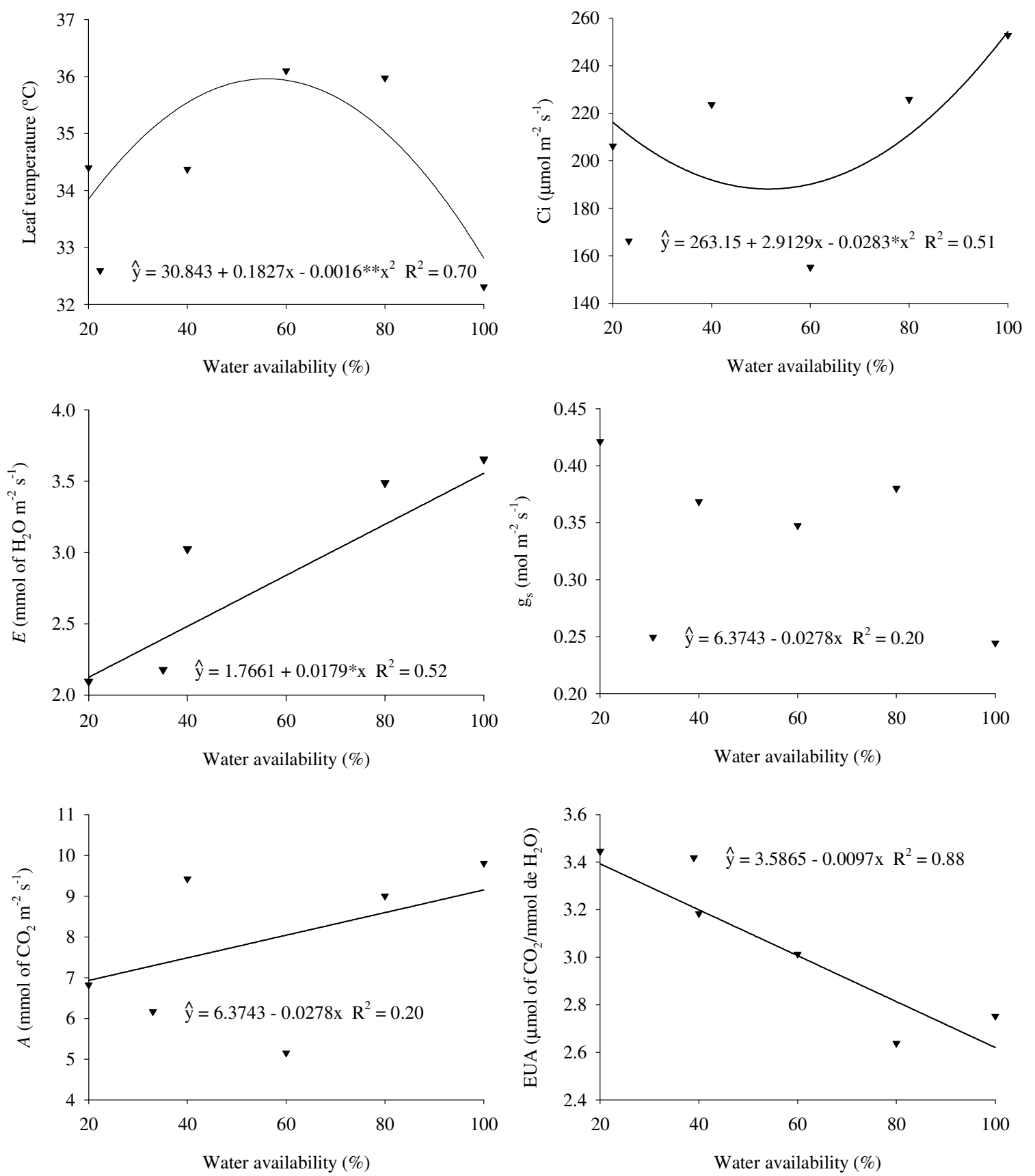

Figure 5. Leaf temperature $\left({ }^{\circ} \mathrm{C}\right)$, internal carbon $(\mathrm{Ci})$, Transpiration $(\mathrm{E})$, stomatal conductance values $(\mathrm{G})$, Photosynthesis (A) and water use efficiency (USA).

\section{CONCLUSION}

For the production of Bauhinia divaricata L. seedlings the initial water regime should be $100 \%$ of the container capacity, but the seedlings will grow satisfactorily under $80 \%$ of the pot capacity. Below $40 \%$ pot capacity the seedlings enter into water stress.

RESUMO: A pata-de-vaca (Bauhinia divaricata L.) é uma espécie arbórea, amplamente distribuída no Brasil, de alto valor ornamental e econômico. Suas folhas são utilizadas nas inflamações renais, como diuréticas, hipoglicemiantes, sendo considerada uma planta medicinal de uso popular. A pesquisa foi desenvolvida em casa de vegetação pertencente ao Laboratório de Ecologia Vegetal, Centro de Ciências Agrárias (CCA), Universidade Federal da Paraíba (UFPB). O Objetivo foi avaliar as características morfofisiológicas em plantas de Bauhinia divaricata em 
diferentes regimes hídricos. O delineamento experimental foi inteiramente casualizado com cinco tratamentos hídrico $100 \%, 80 \%, 60 \%, 40 \%$ e $20 \%$ da capacidade de pote. Avaliou-se, semanalmente a altura, número de folhas e diâmetro do caule. Ao final do experimento as plantas tiveram seus órgãos separados e levados à estufa para obtenção da matéria seca das folhas, caule, raízes e massa seca total, e ainda, alocação de biomassa nas folhas, caule e raízes. A altura de plantas não diferiu estatisticamente entre os tratamentos, o número de folhas, diâmetro, alocação de folhas, caules e raízes e massas seca da raiz e parte aérea foram maiores sob maior disponibilidade de água (100\% da capacidade do recipiente). Para a produção de mudas de B. divaricata L. o regime hídrico deve ser de $100 \%$ e $80 \%$ da capacidade do recipiente, porém as mudas crescem satisfatoriamente.

PALAVRAS-CHAVE: Espécie florestal. Matéria seca. Produção de mudas.

\section{REFERENCES}

ACHTEN, W. M., MAES, W., REUBENS, B., MATHIJS, E., SINGH, V. P., VERCHOT, L., MUYS, B. Biomass production and allocation in Jatropha curcas L. seedlings under different levels of drought stress. Biomass and Bioenergy, v. 34, n. 5, p. 667-676, 2010. http://hdl.handle.net/1854/LU-1055946. Accessed: 24 de ago 2017.

ACHAKZAI, A. K. K.. Effect of water stress on imbibition, germination and seedling growth of maize cultivars. Sarhad Journal of Agriculture, v. 25, n.2, p. 165-172, 2009.

https://www.aup.edu.pk/sj_pdf/EFFECT\%20OF\%20WATER\%20STRESS\%20ON\%20IMBIBITION,\%20GE RMINATION.PDF Accessed: 23 de ago 2017.

ALBUQUERQUE, M. P. F.; MORAES, F. K. C.; SANTOS, R. I. N.; CASTRO, GLEDSON L. S.; RAMOS, E. M. L. S.; PINHEIRO, H. A. Ecofisiologia de plantas jovens de mogno africano submetidas a déficit hídrico e reidratação. Pesquisa Agropecuária Brasileira, Brasília, v. 48, n. 1, p. 9-16, 2013.

http://www.scielo.br/pdf/pab/v48n1/02.pdf Accessed: 12 maio 2017.

ALVES, M. M.; ALBUQUERQUE, M. B.; PEREIRA, W. E.; LUCENA, M. F. A.; AZEVEDO, J. P. S. Morpho-physiological analyses of Allamanda blanchetii A. DC. seedlings under water déficit. Bioscience Journal, Uberlândia, v. 33, n. 5, p. 1134-1143, 2017. http://dx.doi.org/10.14393/BJ-v33n5a2017-36408 Accessed: 12 junh 2017.

ALVES, A. U.; DORNELAS, C. S. M.; BRUNO, R. L. A.; ANDRADE, L. A.; ALVES, E. U. Superação da dormência em sementes de Bauhinia divaricata L. Acta Botânica Brasileira, Belo Horizonte, v. 18, n.4, p. 871-879, 2004. http://www.scielo.br/pdf/\%0D/abb/v18n4/23222.pdf. Accessed: 12 maio 2017.

ARCOVERDE, G. B.; RODRIGUES, B. M.; POMPELLI, M. F.; SANTOS, M. G. Water relations and some aspects of leaf metabolism of Jatropha curcas young plants under two water deficit levels and recovery.

Brazilian Journal of Plant Physiology, Londrina, v. 23, p. 123-130, 2011. http://dx.doi.org/10.1590/S167704202011000200004 . Accessed: 10 maio 2017.

BENINCASA, M. M. P. Análise de crescimento de plantas. Jaboticabal: FUNEP, 1988. 42p.

BERNIER, J. ATLIN, G. N. SERRAJ R. KUMAR A. SPANER D. Breeding upland rice for drought resistance. Journal of the Science of Food and Agriculture, v. 88, n.6, p. 927-939. 2008.

http://onlinelibrary.wiley.com/doi/10.1002/jsfa.3153/abstract Accessed: 24 de ago 2017.

BFG. Growing knowledge: an overview of Seed Plant diversity in Brazil. Rodriguésia, Rio de Janeiro, v. 66, n.4, p. 1085-1113, 2015. http://dx.doi.org/10.1590/2175-7860201566411. Accessed: 10 maio 2017. 
BRIENZA JÚNIOR, S.; PEREIRA, J. F, YARED, J. A. G, MOURÃO, M. J. R, GOLÇALVES, GALEÃO, R. R. Recuperação de áreas degradadas com base em sistema de produção florestal energético madeireiro: indicadores de custos, produtividade e renda. Amazônia: Ciência \& Desenvolvimento. Belém, v. 4, n. 7, p. 197-219, 2008. http://ainfo.cnptia.embrapa.br/digital/bitstream/item/30506/1/Recuperacao-de-Areas-.pdf. Accessed: 12 maio 2017.

CAVALCANTE, A. C. R.; CAVALLINI, M. C.; LIMA, N.R.C.B. Estresse por déficit hídrico em plantas forrageiras. Documentos/Embrapa Caprinos, Sobral, 2009. 50p.

CHAVARRIA, G.; DURIGON, M. R.; KLEIN, V. A.; KLEBER, H. Restrição fotossintética de plantas de soja sob variação de disponibilidade hídrica. Ciência Rural, Santa Maria, v. 45, n. 8, p. 1387-1393, 2015. http://dx.doi.org/10.1590/0103-8478cr20140705 Accessed: 09 set 2017.

DRESCH, D. M., SCALON, S. P. Q. MUSSURY., R. M. KODAMA., F. M. Initial growth of Campomanesia adamantium (Cambess.) o. berg. seedlings on substrates with different compositions and water retention capacities. Bioscience Journal, Uberlândia, v. 32, n. 1, p.1-10, 2016. http://www.seer.ufu.br/index.php/biosciencejournal/article/viewFile/26121/17745. Accessed: 11 jun. 2017.

DUTRA, C. C. PRADO., E. A. F.; PAIM., L. R.; SCALON., S. P. Q. Desenvolvimento de plantas de girassol sob diferentes condições de fornecimento de água. Semina: Ciências Agrárias, Londrina, v. 33: suplemento 1, p. 2657-2668, 2012. http://www.redalyc.org/html/4457/445744117016/. Accessed: 11 jun. 2017.

FERRAZ, A. V; ENGEL, V. L. Efeito do tamanho de tubetes na qualidade de mudas de jatobá (Hymenaea courbaril L. var. stilbocarpa (hayne) lee et lang.), ipê-amarelo (Tabebuia chrysotricha (mart. ex dc.) Sandl.) e Guarucaia (Parapiptadenia rigida (Benth.) brenan). Revista Árvore, Viçosa, v. 35, n. 3, p. 413-423, 2011. http://www.scielo.br/pdf/rarv/v35n3/a05v35n3. Accessed: 09 set 2017.

GONÇALVES, J. G. R. Identificação de linhagens de feijoeiro (Phaseolus vulgaris L.) tolerantes à seca. 2013. 82f. Tese (Doutorado em Agricultura Tropical e Subtropical) - Instituto Agronômico de Campinas, Campinas, 2013.

LARCHER, W. Ecofisiologia vegetal. São Carlos: RIMA Artes e Textos, 2006. 532p.

LENHARD, N. R.; SCALON, S. P. Q.; NOVELINO, J. O. Crescimento inicial de mudas de pau ferro (Caesalpinia ferrea MART. ex Tul. var. leiostachya Benth.) sob diferentes regimes hídricos. Ciência e Agrotecnologia, Lavras, v. 34, n. 4, p. 870-877, 2010. http://dx.doi.org/10.1590/S1413-70542010000400011. Accessed: 10 set 2017.

LEONARDO, M.; BROETTO, F.; BÔAS, R. L. V.; ALMEIDA, R. S.; MARHCESE, J. A. Produção de frutos de pimentão em diferentes condições salinas. Revista Irriga, Botucatu, v. 12, n.1, p. 73-82, 2007.

https://repositorio.unesp.br/bitstream/handle/11449/69435/2-s2.0-34249899140.pdf?sequence=1. Accessed: 10 set 2017.

LORENZI, H. Árvores brasileiras: manual de identificação e cultivo de plantas arbóreas nativas do Brasil. v.2, 2.ed. Nova Odessa: Instituto Plantarum, 2012. 384p.

MARIANO, K. R.; BARRETO, L. S.; SILVA, A. H. B.; NEIVA, G. K. P.; AMORIM, S. Fotossíntese e tolerância protoplasmática foliar em Myracrodruon urundeuva Fr. All. Submetida ao déficit hídrico. Revista Caatinga, Mossoró, , v. 22, n. 1, p. 72-77, 2009. Accessed: 20 nov de 2017. Disponible en:http://www.redalyc.org/articulo.oa?id=237117625010

MARTINS, M. O.; NOGUEIRA, R. J. M. C., AZEVEDO NETO, A. D., SANTOS, M. G. Crescimento de plantas jovens de Nim-Indiano (Azadirachta indica a. Juss. - Meliaceae) sob diferentes regimes hídricos.

Revista Árvore, Viçosa, v. 34, n. 5, p. 771-779, 2010. http://www.scielo.br/pdf/rarv/v34n5/02.pdf. Accessed: 21 mai 2017. 
NASCIMENTO, H. H. C., NOGUEIRA R. J. M. C., SILVA E. C., SILVA M. A. Análise do crescimento de mudas de jatobá (Hymenaea courbaril L.) em diferentes níveis de água no solo. Revista Árvore, Viçosa, v. 35, n. 3, 617-626, 2011. http://dx.doi.org/10.1590/S0100-67622011000400005. Accessed: 21 mai 2017.

PADILHA, N. S., SILVA, C. J., PEREIRA, S. B., NETO DA SILVA, J. A.; HEID, D. M., BOTTEGA S. P., SCALON S. P. Q. Crescimento inicial do pinhão-manso submetido a diferentes regimes hídricos em latossolo vermelho distrófico. Ciência Florestal, Santa Maria, v. 26, n.2, p. 513-521, 2016. http://www.redalyc.org/html/534/53446151015/. Accessed: 24 ago. 2017.

POMPELLI, M. F.; BARATA-LUÍS, R.; VITORINO, H. S.; GONC, ALVES, E. R.; ROLIM, E. V.; SANTOS, M. G.; ALMEIDA-CORTEZ, J. S.; FERREIRA, V. M.; LEMOS, E. E. P.; ENDRES, L. Photosynthesis, photoprotection and antioxidant activity of purging nut under drought deficit and recovery. Biomass and Bioenergy, Oxford, v. 34, p. 1207-1215, 2010. http://dx.doi.org/10.1016/j.biombioe.2010.03.011. Accessed: 24 ago. 2017.

SANTOS, J. C. C. SILVA, C. H., SANTOS, C. S., SILVA, C. S., MELO, E. B., BARROS, A. C. Análise de crescimento e evapotranspiração da cultura do rabanete submetido a diferentes lâminas de água. Revista Verde de Agroecologia e Desenvolvimento Sustentável, Pombal, v. 9, n. 1, 151-156, 2014.

http://www.gvaa.com.br/revista/index.php/RVADS/article/view/2365/2077. Accessed: 21 mai 2017.

SANTOS, P. L, FERREIRA R. A, ARAGÃO A. G, AMARAL, L. A, OLIVEIRA, A. S. Estabelecimento de espécies florestais nativas por meio de semeadura direta para recuperação de áreas degradadas. Revista Árvore, Viçosa, v. 36, n. 2, p. 237-245, 2012. http://www.scielo.br/pdf/rarv/v36n2/a05v36n2. Accessed: 21 mai 2017.

SAPETA, H.; COSTA, J. M.; LOURENCO, T.; MAROCO, J.; VAN DER LINDE, P.; OLIVEIRA, M. M. Drought stress response in Jatropha curcas: Growth and physiology. Environmental and Experimental Botany, Oxford, v. 85, n. 1, p.76- 84, 2013 https://doi.org/10.1016/j.envexpbot.2012.08.0123. Accessed: 21 mai 2017.

SCALON, S. P. Q., MUSSURY, R. M., EUZÉBIO, V. L. M., KODAMA, F. M., KISSMANN, C. Estresse hídrico no metabolismo e crescimento inicial de mudas de mutambo (Guazuma ulmifolia Lam.). Ciência Florestal, Santa Maria, v. 21, n. 4, p. 655-662, 2011.

https://periodicos.ufsm.br/cienciaflorestal/article/view/4510/2671. Accessed: 21 mai 2017.

SILVA, E. C., NOGUEIRA, R. J. M. C., VALE, F. H. A.; ARAÚJO, F. P., PIMENTA, M. A. Stomatal changes induced by intermittent drought in four umbu tree genotypes. Brazilian Journal of Plant Physiology, Campos dos Goytacazes, v. 21, n. 1, p. 33-42, 2009. http://dx.doi.org/10.1590/S1677-04202009000100005 Accessed: 21 mai 2017.

SILVA, M. B. R., FERNANDES, P. D., DANTAS, NETO, J. NERY, A. R.; RODRIGUES, L. N., VIÉGAS, R. A. Crescimento e produção do pinhão-manso irrigado com água residuária sob condições de estresse hídrico. Revista Brasileira de Engenharia Agrícola e Ambiental, Campina Grande, v. 15, n. 6, p. 621-629. 2011. http://www.scielo.br/pdf/rbeaa/v15n6/v15n06a13.pdf. Acesso em: 24 ago. 2017. Accessed: 21 mai 2017.

SIMÕES, W. L.; CALGARO,, M.; COELHO, D. S.; SOUZA M. A.; LIMA, J. A. Respostas de variáveis fisiológicas e tecnológicas da cana-de-açúcar a diferentes sistemas de irrigação. Revista Ciência Agronômica, Fortaleza, v. 46, n. 1, p. 11-20, 2015. http://www.scielo.br/pdf/rca/v46n1/0045-6888-rca-46-01-0011.pdf Accessed: 21 mai 2017.

SOUZA, C. C.; OLIVEIRA, F. A.; SILVA, I. F.; AMORIM NETO.; M. S. Avaliação de métodos de determinação de água disponível e manejo da irrigação em terra roxa sob cultivo de algodoeiro herbáceo.

Revista Brasileira de Engenharia Agrícola e Ambiental, Campina Grande, v. 4, n. 3, p. 338-342, 2000. http://dx.doi.org/10.1590/S1415-43662000000300006. Accessed: 13 agost. 2017. 
TAIZ, L.; ZEIGER, E. Fisiologia Vegetal. 6. ed. Porto Alegre: Artmed. 2017. 888 p.

TATAGIBA, S. D. , XAVIER, T. M. T. TORRES, H. , PEZZOPANE, J. E. M. CECÍLIO R. A. ZANETTI S.

S. Determinação da máxima capacidade de retenção de água no substrato para produção de mudas de eucalipto em viveiro. Floresta, Curitiba, v. 45, n. 4, p. 745-754, 2015. http://dx.doi.org/10.5380/rf.v45i4.38334.

Accessed: 12 jun. 2017. 